\title{
Could Netarsudil be the promising treatment of Glaucoma?
}

\author{
Mina Abdelmseih* \\ Department of Fulda Eye Clinic, Germany
}

*Corresponding author: Mina Abdelmseih, Department of Fulda Eye Clinic, Germany.
Received Date: March 04, 2019

Published Date: March 12, 2019

\section{Editorial}

Glaucoma is a group of chronic optic neuropathies characterized by degenerative changes in the optic nerve and visual field loss [1]. Intraocular pressure is considered the major risk factor for the progression of glaucomatous optic neuropathy involving the death of retinal ganglion cells and their axons [2].

However, glaucoma pathogenesis is not fully understood, the degeneration of retinal ganglion cells is related to increased intraocular pressure level. The intraocular pressure is determined by the balance between the ciliary body's secretion of aqueous humor and its drainage through two independent pathways: the trabecular meshwork and uveoscleral pathway. There is increased resistance to aqueous outflow through the trabecular meshwork in patients with open-angle glaucoma. In contrast, in patients with angle-closure glaucoma, access to the drainage pathways is typically obstructed by iris [3].

Netarsudil ophthalmic solution $0.02 \%$ [Rhopressa ${ }^{\circledR}$ ] is a Rhoassociated protein kinase (ROCK) inhibitor that primarily reduces intraocular pressure (IOP) by increasing the outflow of aqueous humor through the trabecular meshwork pathway. It is recently approved for the reduction of elevated IOP in patients with openangle glaucoma or ocular hypertension in the United States. The recommended dosage is once daily in the evening one drop in the affected eye(s). For this indication, there are ongoing researches: Phase III development in the EU, and Phase II development in Japan [4].

In three phases III trials of patients with elevated IOP, in patients with a baseline IOP less than $25 \mathrm{mmHg}$, the ocular hypotensive efficacy of once-daily $0.02 \%$ met the non-inferiority criteria for twice-daily timolol $0.5 \%$ over 3 months. The most common side effects are mild conjunctival hyperemia without increasing the severity with the continued dose, subconjunctival hemorrhages and cornea verticillata. Also, serious or systemic side effects related to treatment are uncommon probably due to a lack of systemic exposure [5].

According to a study by Kazemi A, McLaren JW, and Kopczynski which is designed to evaluate the effect of netarsudil $0.02 \%$ on aqueous humor dynamics (AHD) parameters. In this doublemasked study, 11 healthy volunteers received topical netarsudil ophthalmic solution $0.02 \%$ once a day for 7 days (morning dosage).

The difference between netarsudil and placebo eyes in diurnal outflow change was $0.08 \mu \mathrm{L} / \mathrm{min} / \mathrm{mmHg}(\mathrm{P}<0.001)$. Diurnal episcleral venous pressure (EVP) decreased in netarsudil-treated eyes from $7.9 \pm 1.2 \mathrm{mmHg}$ to $7.2 \pm 1.8(-10$ percent; $\mathrm{P}=0.01)$. Diurnal EVP was not significantly different between netarsudil and placebotreated eyes. Once a day, netarsudil ophthalmic solution $0.02 \%$ reduced IOP by increasing trabecular outflow and reducing EVP. This suggests a combination of mechanisms that affect both the proximal and distal outflow pathways [6].

The development of Rho kinase inhibitors for the reduction of IOP in patients with glaucoma and ocular hypertension is a triumph of medical research. Rho kinase inhibitors agents are thought to be very effective alone or in combination with other glaucoma medications. Netarsudil has neuroprotective and antifibrotic properties and enhances ocular blood flow. Therefore, it may be considered a revolutionary medication in the medical and surgical treatment of glaucoma [7].

\section{Acknowledgment}

None.

\section{Conflicts of Interest}

Author declares no Conflicts of Interest. 


\section{References}

1. Weinreb RN, Khaw PT (2004) Primary open-angle glaucoma. Lancet 363(9422):1711-1720.

2. Mina Abdelmseih (2017) Why Should SLT be the First-Choice Treatment for Glaucoma? JOJ Ophthal 4(1): 555630

3. Weinreb RN, Aung T, Medeiros FA (2014) The Pathophysiology and Treatment of Glaucoma: A Review. JAMA 311(18):1901-1911.

4. Hoy SM (2018) Netarsudil Ophthalmic Solution 0.02\%: First Global Approval. Drugs 78(3): 389-396.
5. Kopczynski CC, Heah T (2018) Netarsudil ophthalmic solution $0.02 \%$ for the treatment of patients with open-angle glaucoma or ocular hypertension. Drugs Today (Barc) 54(8): 467-478.

6. Kazemi A, Mc Laren JW, Kopczynski CC, Heah TG, Novack GD, et al. (2018) The Effects of Netarsudil Ophthalmic Solution on Aqueous Humor Dynamics in a Randomized Study in Humans. J Ocul Pharmacol Ther 34(5): 380-386.

7. Tanna AP (2018) Johnson M Rho Kinase Inhibitors as a Novel Treatment for Glaucoma and Ocular Hypertension. Ophthalmology 125(11): 17411756 